УДК 330.101 .2

Мілай А.О.

канд. економ. наук, доиент Національний технічний університет Украйни «КПI»

\title{
МЕТОДОЛОГІЧНИЙ ПІДХІД К АНАЛІЗУ ТЕОРІЇ ЕКОНОМІЧНОЇ КРИЗИ І ЕКОНОМІЧНОГО РОЗВИТКУ
}

\author{
МЕТОДОЛОГИЧЕСКИЙ ПОДХОД К АНАЛИЗУ ТЕОРИИ \\ ЭКОНОМИЧЕСКОГО КРИЗИСА И ЭКОНОМИЧЕСКОГО РАЗВИТИЯ
}

\section{METHODOLOGICAL APPROACHES TO THE ANALYSIS OF THE THEORY OF ECONOMIC CRISIS AND ECONOMIC DEVELOPMENT}

В досліджені проводиться аналіз системи розподілу пращі з позицій теорії трудової вартості. Визначається, щчо єдиним базовим ресурсом економічної системи є праця, усі інші матеріальні ресурси є похідними і розкладаються на живу $і$ уречевлену пращю. В економічній системі відокремлюється об'єкт по відношенню до якого проводиться аналіз рівня розподілу праці, визначаються основні проблеми розвитку системи розподілу праці $і$ шляхи їх вирішення капіталістичної системою господарства. Розглядається проблема отримання прибутку на рівноважному ринку. В той же час, визначається помилковість деяких положень сучасної економічної теорії стосовно моделі утворення прибутку в реальному секторі економіки, основних чинників виникнення диспропориій у виробництві $i$ споживанні, появи безробіття, економічної кризи і стагнації. Аналізуються особливості виробництва інноваційної продукиії і інноваційного процесу в сучасній економічній системі.

Ключові слова: економічна криза, рівень розподілу праці, продуктивність праці, додаткова вартість, прибуток, система техно-економічного відтворення.

В статье проводится анализ системы разделения труда с позиции теории трудовой стоимости. Определяется, что единственным базовым ресурсом экономической системы является труд, все другие материальные ресурсы являются производным и раскладываться на затраты живого и овеществленного труда. В экономической системе выделяется объект, по отношению к которому проводится анализ уровня разделения труда, определяются основные проблемы развития системы разделения труда и пути их решения. Рассматривается проблема получения прибыли на равновесном рынке. В то же время, определяется ошибочност, некоторых представлений современной экономической теории относительно модели формирования прибыли в реальном секторе экономики, основных факторов возникновения диспропорщий в производстве и потреблении, причин экономического кризиса, безработиць и стагнации. Анализируются особенности производства инновационной продукиии и инновачионного процесса в современной экономической системе.

Ключевые слова: экономический кризис, уровень разделения труда, производительность труда, прибавочная стоимость, прибыль, система техно экономического воспроизводства. 
The article analyses the system of division of labour from the perspective of the labour theory of value. Determined that the only resource base of the economic system is the work of all other material resources are derived and displayed on the costs of labour and materials. The economic system is allocated an object in relation to which the analysis of the level of division of labour, identifies the main problems of the division of labour and their solutions. The problem of making a profit on the market equilibrium. At the same time, is determined by the error of some concepts of modern economic theory regarding the formation of profit model in the real economy, the main factors leading to imbalances in production and consumption, the causes of the economic crisis, unemployment and stagnation. It is concluded that the production of innovative products possible in the first place, at a certain level of development of the division of labour, and secondly, in the economic system, where there is a sufficient number of labour force, which provides production and consumption of a certain number of products. The features of the production of innovative products and innovative processes in the modern economic system.

Keywords: economic crisis, the level of division of labour, productivity, surplus value, profit, system of techno-economic reproduction.

Вступ. Дослідженню проблематики теорії кризи та проблем економічного зростання присвячено багато праць вітчизняних і західних науковців, найбільш відомі 3 них - Й.Шумпетер[1], Абалкін Л.И [2], Гальчинський А.С [3], Гєлбрейт Дж. [4], Макконел К. [5], Геєць В.М [9].

Однак, на сучасному етапі розвитку економічної теорії залишається багато актуальних економічних питань на які фахівці не дають однозначної відповіді. Чому, наприклад, існує на протязі століть невелика, майже постійна, кількість розвинутих країн і поряд 3 ними сотні, так званих, країн які розвиваються? В чому полягає причина економічних криз? Чому не співпадає тренд економічного циклу країн, які, так чи інакше, $є$ часткою світової економіки? Чому політика кількісного пом'якшення, хоча і збільшила баланс ФРС с 2008 року більш ніж в чотири рази, не призводить до бажаного рівня інфляції в розмірі 2\% на рік, більш того дефляційна криза продовжується?

На ці та інші питання, в межах існуючої економічної парадигми, світове суспільство, так чи інакше, не знаходить однозначної відповіді.

Постановка завдання. Основною метою наукової статті є визначення методологічного підходу к дослідженню природи економічного зростання $\mathrm{i}$ економічної кризи.

Завдання роботи полягають в аналізі моделі отримання прибутки в рівноважній економічній системі, а також основних чинників виникнення диспропорцій у виробництві і споживанні, появи безробіття, економічної кризи і стагнації. Окреме завдання дослідження полягає в визначені певних особливостей виробництва інноваційної продукції і інноваційного процесу в сучасній економічній системі.

Методологія дослідження. Теоретичною та методологічною основою статті $є$ роботи вітчизняних і зарубіжних вчених в галузі дослідження природи економічної кризи. У роботі використовувались загальнонаукові та спеціальні методи дослідження економічних процесів i явищ. Iз 
загальнонаукових методів застосовано: абстрактно-теоретичний, діалектичний, аналізу і синтезу та інші, які були використанні при узагальненні теоретикометодологічних положень

Результати дослідження. Економічна криза, так чи інакше, завжди $\epsilon$ наслідком порушення циклу відтворення, коли, в певних умовах, наступний цикл виробництва не може поновлюватись в попередніх масштабах.

Як відомо, мета капіталістичного виробництва отримання прибутку. Отже, коли підприємець немає можливості отримувати прибуток, тобто реалізувати основну мету своєї діяльності, виробництво згортається і натупає криза. Вона може триматися до тих пір поки знову не з'явиться можливість для більшості виробників отримувати прибуток.

Здавалося б, простий і зрозумілий механізм економічної кризи. Але, насправді, виникає багато питань які, на нашу думку, досить тривалий час вимагають відповіді. Наприклад, чому економічні кризи притаманні тільки капіталістичному виробництву? Чому на протязі тисяч років ринкове господарство не знало проблеми економічної кризи i чому перша світова економічна криза 1857-1858 років стає повною несподіванкою?

До початку Великої депресії в 1929 році, економісти в повній відповідності до закону Сея, взагалі серйозно не розглядали можливість світової кризи. Була поширена думка, що на рівноважному ринку сукупний попит завжди поглинає весь обсяг виробленої продукції. Тобто, виробництво, саме по собі, створює адекватний за розміром попит. I це положення класичної економічної теорії є, безумовно, справедливим. Іншими словами, на макрорівні об'єктивно діє закон у відповідності з яким перш ніж на ринку реалізувати певний обсяг вартості треба спочатку створити платоспроможний попит якій дорівнює розміру цієї вартості.

Сутність закону Сея зводиться до простого економічного механізму. Підприємець, якій організовує виробництво, спочатку купує обладнання, сировину, матеріали, комплектуючи, створюючи попит на матеріальні фактори виробництва, потім він купує робочу силу, створюючи платоспроможний попит з боку найманих працівників. Таким чином, вироблена продукція по вартості повністю відповідає попереднім витратам i тому може бути реалізована, тому що під неї на ринку вже створений відповідний платоспроможний попит. Дію цього механізму неможливо заперечити тому і закон Сея є фундаментальним законом економічної теорії.

Секрет процесу відтворення полягає в тому, що відповідний попит створюється на стадії організації виробництва, тобто передує споживанню, а не навпаки. В моделі ринкового господарства виробництво робить попит можливим не тільки тому що виготовлює певну продукцію, а перш за все, тому що робить його повністю платоспроможним. В свою чергу, реалізація стадії споживання у процесі відтворення робить можливим поновлення циклу виробництва. В цьому, власно кажучи, і полягає нерозривний зв'язок між 
споживанням i виробництвом, який забезпечує безперервний цикл відтворення.

На нашу думку, необхідність аналізу такого простого і незаперечливого закону виникає тому, що багато хто 3 економістів не розуміє основні наслідки його діє. Адже головний наслідок полягає в тому, що у виробництві не створюється додаткова вартість, яка так чи інакше приймає форму прибутку. Вона не створюється, тому що на попередньому етапі відтворення, на стадії виробництва, під реалізацію цієї вартості не було створено платоспроможного попиту. А від так, по закону товарного ринку, те шо на рівні абстрактної ринкової моделі не має можливості бути реалізованим ринкової вартості немає.

Заперечення створення додаткової вартості, можна отримати і з іншого боку. Усім відома формула Т(а) - Г - Т(б). Як відомо, вона описує звичайний акт обміну на ринку. Два суб'єкта ринку зустрічаються для обміну товарів або послуг через посередництво грошей. 3 часів К. Маркса, багато хто 3 економістів вважає, що в цьому акті обміну обидва суб'єкта отримують прибуток, доречи, в супереч класичної теорії Адама Сміта. В свій час, щоб пояснити феномен отримання прибутку К. Маркс, пішов на пряме порушення законів ринку. Він наділив робочу силу особливою якістю створювати вартість яка перевищую власну ціну[6].

Окрім попередніх зауважень, ми хотіли б нагадати економістам, які підтримують таку точку зору, про основний висновок що витікає 3 принципу ефективності по Парето. А саме те, що на ринку суб'єкти не можуть мати вигоду через еквівалентний акт обміну товарів чи послуг. Треба визнати один 3 двох взаємовиключних наслідків. Або погодитися з тим що на ринку постійно обмінюються не еквівалентні вартості, тобто одні суб'єкт обміну постійно отримують прибуток, а інші збиток, або визнати, все ж таки, еквівалентний обмін, і як наслідок, неможливість отримання прибутку в звичайному акті обміну. На нашу думку, відповідь очевидна.

I дійсно, якщо ми навіть припустимо що робоча сила має особливу властивість створювати у процесі виробництва вартість, яка перевішує їі ціну, то тоді по закону ринка, попит на такий товар буде перевищувати його пропозицію i, через деякий час, ціна зросте до рівня вартості, а тому вартість $\mathrm{i}$ ціна робочої сили все одно прийдуть до рівноваги. Висновок простий. В моделі відтворення ринкового типу не можливо спочатку отримати прибуток, а потім під цю вартість створити відповідний попит з боку підприємців.

Але окрім теоретичних модельних побудов $є$ реальне економічне життя в якому більшість підприємств прибуток мають. Таким чином, виникає питання як утворюється прибуток? Відповісти на це питання досить складно, але необхідно. Адже саме, отримання прибутку, так чи інакше, пов'язане в капіталістичному виробництві з економічною кризою. 
Для відповіді треба, по-перше, погодитися з тим, що процес відтворення відбувається в певній системі розподілу праці, i, по-друге, визначити в яких саме межах він здійснюється. Ми звикли до поняття відтворення сукупного суспільного продукту. I розуміємо цей процес, як макроекономічну модель в межах якої постійно, на рівні національної економіки, виробляється i споживається певна вартість. При цьому, ми розуміємо простір виробництва і споживання, в такій моделі як, більш - менш, однорідний. Але, якщо уважно придивитися до умов в яких дійсно відбувається процес відтворення відразу з'ясовується, що в будь якій національній економіці представлені відразу декілька зовсім різних видів відтворення, які належать до різних систем розподілу праці.

Так, наприклад, в економіці будь-якою країни $\epsilon$ виробництва які відтворювальний цикл починають і завершують в межах одного регіону. $€$ такі, що охоплюють декілька регіонів, або рівень національної економіки. I, нарешті, ті що потребують для свого відтворення поєднання простору національних економік декількох країн, i, навіть, світової економіки в цілому.

Різниця між цими типами відтворення дуже суттєва. Вона полягає в системі розподілу праці на яких вони базуються. А, від так, і в кількості людських ресурсів які їм потрібні для поновлення циклу. Тобто, $\epsilon$ виробництво, для відтворення якого потрібно декілька сотень або тисяч населення, а є виробництва, що потребують сотні тисяч і десятки мільйони робочої сила, пов'язаної між собою єдиною системою розподілу праці.

В перше увагу, на залежність можливості виробництва певного виду продукції від рівня розвитку системи розподілу праці, звернув Адам Сміт. В своїй роботі[10] він розглядає умови в яких можливе появлення на ринку інноваційною продукції. Прикладом йому слугувало виробництво, так званої, «куртки поденщика». Адам Сміт робить висновок про те, що інноваційне виробництво можливе тільки при досягнення певного рівня розвитку системи розподілу праці, він називає це глибиною розподілу праці.

Так для того щоб виробити досить дешеву i якісну куртку, в якій найманий працівник щоденно може ходити на роботу, необхідна, наприклад, певна кількість бавовни, вовни, барвників для тканини, гудзики и т.п. Однак зрозуміло, що налагоджувати постійні морські перевезення сировини в Англію, не можливо заради виробництва невеликої партії такої продукції, потрібен стійкій довготривалий попит і не тільки на куртки, але й на багато іншої продукції, яка потребує для свого виготовлення подібну сировину.

Теж саме стосується i знаряддя праці, що використовується у виробництві. Наприклад, потрібні ножиці, щоб розрізати тканину, і знову ж таки, заради виготовлення партії ножиць не будуть розробляти шахти добувати руду и плавити метал. Подібна ситуація виникає і з обладнанням, на якому цю куртку шиють і т.д. 
Таким чином, зробити ескіз куртки і виготовити необхідні лекала можливо було і в XIVcт. i, безумовно, значно раніше, але запустити в процес виробництва, масово виробляти певну інноваційну продукцію стає можливим тільки тоді коли, по-перше, виникає відповідний попит на певний асортимент продукції, а, по-друге, достатньо розвинута система розподілу праці.

Підкреслимо ще раз висновок, якій потрібен для подальшого аналізу. Адам Сміт на цьому дуже вдалому, на нашу думку, прикладі, поясняє, що виробництво і відтворення тих чи інших продуктів можливе, по - перше, при певному рівні розвитку системи розподілу праці, по-друге, в економічній системі, де є достатня кількість робочої сила, яка забезпечує не тільки кожний новий цикл відтворення виробництва продукції, але й іiї споживання в відповідних розмірах.

Продовжимо дослідження Адам Сміта на прикладі іншої ситуації. Припустимо що на ринку представлено N - видів різної продукції. Виникає питання як змінюється асортимент ринку, коли на ньому з'являється новий вид продукції? Іншими словами, асортимент на ринку збільшиться на одиницю i буде складати кількість - N+1, чи, може, наприклад, $\mathrm{N}+1000$ видів продукції?

Для відповіді на це питання знову розглянемо приклад. Так на початку ХХст., з'являються перші автомобілі. Для того щоб забезпечити появу на ринку цієї інноваційної продукції потрібно було налагодити виробництво двигунів, ходової частини, оздоблення салону, а також, системи керування, колес i т. д. А скільки треба було створити нових інноваційних видів продукції, щоб запустити виробництво тільки двигунів для автомобіля? I, якщо врахувати усі ці види нового виробництва, які забезпечують появу тільки одного виду інноваційної продукції, то ми отримаємо дуже значне інноваційне зростання ринку.

В той же час, важливо звернути увагу ще на одну проблему. Вибухове зростання інновацій на ринку, вимагає притоку значної і навіть дуже значної додаткової кількості робочої сили, притому ще й певного рівня освіти і кваліфікації. А, власно кажучи, в суспільстві, яке стає на індустріальний шлях розвитку, таким резервом може бути тільки сільське населення. Але такий резерв, на певному етапі розвитку системи розподілу праці, обов'язково, i доречи порівняно швидко, закінчується. I тоді виникає питання про можливість подальшого втілення інновацій, а від так і економічного зростання взагалі.

Висновки, які можна зробити з цих прикладів полягають в наступному. По - перше, економічне зростання відбувається на основі розвитку системи розподілу праці. По - друге, таке економічне зростання потребує досить великого резерву робочої сили. I, нарешті, ще один важливий висновок, без кризове економічне зростання можливе при збережені певних пропорцій між виробництвом і споживанням, які склалися на попередньому етапі розвитку системи розподілу праці. 
Іншими словами, економічне зростання це процес поступової побудови системи розподілу праці, яка $\epsilon$ дуже точно збалансованою по обсягам виробництва і споживання. У цьому зв'язку треба згадати, що в радянські часи досить ефективним інструментом управління економікою була розробка i використання міжгалузевих балансів, через які забезпечувалась планова координація виробництва і споживання усього господарського комплексу. А, як відомо, міжгалузеві баланси, так чи інакше, відображали систему розподілу праці яка існувала на той час.

В сучасній економічній теорії вважається, що розподіл праці по всій економічній системі, більш - менш, рівномірний. В реальній економічній дійсності ми бачимо зовсім іншу картину. Усі підприємства через кооперацію об'єднуються в певні системні групи. В даному випадку, критерієм об'єднання $\epsilon$ рамки в яких відбувається повний цикл відтворення певного асортименту продукції, якій $є$ повністю самодостатнім для незалежного існування такої системної групи. I, якщо виділити такі групи підприємств, ми зрозуміємо, що для кожної групи існують різні масштаби економічного простору для відтворення виробництва і споживання.

Цей ланцюжок починається з простого натурального господарства, яке $€$ в принципі самодостатнім, і закінчується великими групами підприємств, об'єднаних кооперацією в глобальну систему розподілу праці, яка свій відтворювальний цикл здійснює на усьому економічному просторі світового господарства. Різниця між цими типами відтворення полягає, перш за все, в системі розподілу праці яку вони використовують для виробництва i споживання. А від так, і в кількості ресурсів яка їм необхідні для поновлення циклу.

Про які ресурси йде мова коли досліджується модель відтворення? В нашому аналізі ми дотримуємося принципового методологічного положення теорії трудової вартості Адама Сміта, відповідно 3 яким, будь який матеріальний ресурс, використаний у виробництві, завжди можна представити як витрати праці - живої і уречевленої [10]. Так, підприємство в процесі виробництва завжди витрачає живу i уречевлену працю, в свою чергу, використану уречевлену працю, можна також розкласти на витрати праці живої і уречевленої і т.д. Тобто, в моделі відтворення є нематеріальний базовий ресурс - праця, а усі інші ресурси - матеріальні, і $є$ похідними від базового.

Таким чином, стає очевидним, що єдиним і достатнім ресурсом якій дійсно має значення для розвитку економічної системи $є$ праця. А єдиним джерелом зростання продуктивності праці $€$ поглиблення системи іiі розподілу. В кінцевому варіанті, високий рівень продуктивності праці підприємство отримує не тому, що воно використовує новітнє обладнання і надсучасні матеріали, а тому, що воно існує в певній системі розподілу праці, яка може забезпечити їх виробництво і споживання. 
Підтверджує цей висновок приклад економіки радянських часів. Більшість економістів вважає, що Радянський Союз програв економічне змагання с заходом тому що мав значно меншу продуктивність праці. В той же час, ми добре знаємо, що на початку 80-х років радянська економіка по рівню конвеєризації виробництва займала перше місце в світі. А будь кому відомо, що продуктивність праці на конвеєрі задає швидкість його руху. На підприємствах Радянського Союзу вона була вище ніж в розвинутих країнах.

Проблема ефективності радянської економіки була в іншому. Перш за все, це невчасна комплектація виробництва, яка, в той же час, супроводжувалась високим відсотком браку комплектуючих. Як наслідок, підприємства або взагалі зупинялись, або намагалися самостійно, на власних потужностях, виробляти ті чи інших комплектуючи, тобто, власно кажучи, переходили від сучасної системи розподілу праці до рівня періоду індустріалізації радянської економіки.

Безумовно, зниження сучасного, на той час, рівня розподілу праці, хоча частково і вирішувало питання дефіциту продуктів, тим не менш, значно поменшувало ефективність виробництва.

C середини 60-х років минулого століття, економіка Радянського Союзу потрапила в замкнуте коло. Причинної було те що скінчився резерв робочої сили необхідний для подальшого розвитку системи розподілу праці. Як відомо, до того часу таким резервом економічного розвитку слугувало сільське населення. В таких умовах було легко досягти економічного зростання, навіть не розвиваючи систему розподілу праці. Кожний новий робітник, якій приходив у промисловість з сільського господарства і ставав до станка, відразу значно збільшував продуктивність своєї праці, бо на промисловому підприємстві у порівняні з сільським господарством вона в рази була вища. Використовувався, так званий, екстенсивний тип розширеного відтворення виробництва. Резерви інтенсивного типу відтворення, пов'язаного 3 розвитком системи розподілу праці в 30 - ті роки, по тій самій причині, скінчилися ще раніше.

Настав тривалий час економічного застою. В реальному економічному житі це виглядало наступним чином. Збільшення фондоозброєння виробництва, на окремих підприємствах, призводило до того що ефективність від зниження витрат живої праці, за рахунок використання додаткових машин і устаткування, значно перекривалося витратами на будівництво нових підприємств де ці машини і обладнання виготовлювались. Тобто, в цілому ефективність економіки країни не зростала. Людські ресурси для розвитку системи розподілу праці були вичерпані.

Вивчення досвіду економіки радянських часів дає можливість зробити висновок, що саме система, або глибина розподілу праці, в якій знаходиться те чи інше виробництво і визначає його ефективність. А економічний розвиток це поступове поглиблення системи розподілу праці. Власно кажучи, саме цей 
висновок робить Й. Шумпетер коли аналізує різницю між економічним зростанням і економічним розвитком[1].

Виникає питання, в рамках якої економічної моделі відбувається розвиток системи розподілу праці? Іншими словами, стосовно якого об'єкту повинна здійснюватися оцінка системи розподілу праці?

Визначимо основні системні ознаки такого об'єкту на рівні абстрактної моделі. По - перше, система ця повинна бути відносно замкнута по виробництву і споживанню основних товарів і послуг. По - друге, вона повинна бути самодостатня, тобто забезпечувати задіяних в ній економічних суб'єктів усіма необхідними для розвитку ресурсами, і в той же час, бути здатної повністю споживати і відтворювати задіяні в ній ресурси. Нарешті, вона повинна мати власні стимули для розвитку.

Ми пропонуємо назвати таку самодостатню систему в межах якою постійно відбувається відтворення технологічних i економічних умов виробництва і споживання - системою технологічного i економічного відтворення, або контуром відтворення. Єдиний базовий ресурс, який обертається в такій системі - це праця. Усі інші ресурси, так чи інакше, $є$ похідним від праці і можуть бути розкладенні на витрачений ресурс живої праці і уречевленої праці. Сдиним джерелом зростання продуктивності базового ресурсу є поглиблення системи розподілу праці. Одним з обмежень його зростанні $є$ ліміт робочої сили, яка може бути задіяна в процесі відтворення даної техно-економічної системи.

Система техно-економічного відтворення це гіперкомплексна система, яка, в свою чергу, складається з чотирьох самостійних кластерних систем виробництво, розподіл, обмін і споживання. Кожна наступна система $\epsilon$ похідною від попередньої, а остання - споживання, стає економічною основою для початку нового циклу відтворення.

Визначимо три основних базових принципи на яких формується система техно-економічного відтворення. Перший - принцип фракталізації, реалізується в алгоритмі побудови складних структурних композицій на базі початкового прототипу. Таким початковим прототипом для сучасної системи техно-економічного відтворення стала капіталістична фірма. Основні методологічні підходи к аналізу її економічної природи ми досліджували в роботі [8].

Яким чином фрактальна гіперкластерна система може стабільно існувати в розгорнутій формі? Основної умовою $є$ мінімізація тенденцій до внутрішніх конфліктів і протирічь. Тобто, структурна основа системи повинна бути узгодженою і компліментарною. Це і $є$ другім базовим принципом.

Третій базовий принцип полягає в наявності певних бар'єрний обмежень, перехідних мембран, між основними структурними елементами системи, які створюють умови для їх економічної і фінансової незалежності. 
Сучасна система розподілу праці розвинутих країн, тобто панівна система техно-економічного відтворення, охоплює понад мільярд населення. Побудована вона по принципу дитячого конструктора Лего. В середині неї, за рахунок високого рівня стандартизації i уніфікації, створена деяка технологічна множина, якою постійно користуються конструктори i виробники інноваційної продукції. Саме це дає можливість налагоджувати масове виробництво нових зразків продукції без потреби задіяти значні додаткові резерви робочої сили.

Ознакою того, що економіка країни належить до панівної в світі системи відтворення $\epsilon$ те що іiі національна валюта входить до кошика резервних світових валют. Це, перш за все, визначається тим, що достатність грошей була і залишається основною умовою розвитку системи розподілу праці.

На нашу думку, використання поняття - система техно-економічного відтворення - $є$ важливим методологічним інструментом. Наприклад, стає можливим пояснити походження прибутку в реальному секторі економіки.

Так, модель техно-економічного відтворення, рівноважна. В ній діє принцип ефективності по Парето і вона не створює економічних умов для отримання прибутку в звичайних операціях обміну. Виникає питання, яким чином отримують прибуток суб’єкти що задіяні в певному контурі відтворення?

В площині світового ринку одночасно присутня значна кількість систем техно-економічного відтворення, економічні кордони між ними досить умовні. Усі вони, перш за все, відрізняються глибиною системи розподілу праці, а від так і продуктивністю робочої сили, яка в них задіяна. В свою чергу, продуктивність робочої сили, це основний чинник який визначає іiї вартість. Вартість робочої сила, задіяної в розвинутій системі розподілу праці, висока і дуже висока, а, відповідно, вартість робочої сили, яка працює в контурі відтворення 3 порівняно невисоким рівнем розподілу праці досить мала. Різниця в вартості товару робоча сила в різних системах техно-економічного відтворення і є джерелом прибутку.

Товар робоча сила дійсно особливий в порівнянні з будь яким іншим ресурсом. Так, наприклад, обладнання яке виготовлене в одній системі розподілу праці, як правило, технологічно неможливо використовувати в іншій системі, хоча економічний сенс, в наслідок різниці в його собівартості і продуктивності, безумовно, i існує Теж саме стосується комплектуючих i, в значній мірі, матеріалів. Виключення складає сировина. Її можливо використовувати, в будь якій системі відтворення, незалежно від того де іiі видобули. Але в цьому випадку зникає економічний сенс її використання, як джерела прибутку, тому що усю ренту, яку можна отримати 3 сировини забирає, як правило, власник копалин, або країна експортер. В той же час, праця, як ресурс що належить одному контуру відтворення, майже завжди зберігає технологічну можливість і економічний сенс іiі використання в будь - 
якому іншому контурі відтворення. I тому різниця в їі вартості стає джерелом прибутку.

Таким чином, коли частина виробництво одного контуру відтворення переноситься на економічну територію іншого, різниця в вартості товару робоча сила зберігається і стає джерелом прибутку. Саме це є причиною того, що час від часу, ми маємо можливість спостерігати появу економічних див швидкого зростання економіки окремих країн. Як наслідок цього процесу, в економіці країн з розвинутою системою розподілу праці, виникає безробіття и стагнація виробництва. Тобто, загальний рівень виробництва зменшується, а ціни на продукцію знижуються, тому що зменшуються витрати на заробітну плату в цьому ж контурі відтворення але розташованому в іншій країні. Детально цей процес ми аналізуємо в роботі «Проблеми і наслідки взаємодії країн в процесі відтворення виробництва».

Виникає парадоксальна ситуація: система відтворення, до якої належить економіка країни, може розвиватися і виробництво зростати, а національна економка самої країни знаходитись в кризовому стані. Це пояснюється тим, що національна економіка країни і система відтворення до якої вона належить, не тільки не співпадають за розмірами, а й розвиваються за різними економічними законами. В такій ситуації політика «дешевих грошей», яку останнім часом проводять розвинуті країни, з метою досягти зростання цін $і$ пожвавлення виробництва, як правило, не дає результатів.

Таким чином, виникає дисбаланс між виробництвом і споживанням в системи відтворення, яка є панівною в світі, і це призводить до глобальної економічної кризи. Сдиний шлях загальмувати розвиток світової кризи, це, попре все, підтримувати споживчий попит. Власно кажучи, ми це бачимо на прикладі проведення політики кількісного пом'якшення в США, Свропі i Японії. Досить детально особливості і наслідки сучасної світової монетарної політики ми розбираємо в роботі $[7,91]$.

Висновки. Проведене дослідження дає можливість зробити висновок про те що економічне зростання, це поступовий розвиток системи розподілу праці, яке відбувається в межах системи техно-економічного відтворення. В той же час, аналіз взаємодіє між різними системами відтворення дає можливість пояснити:

по-перше, походження диспропорцій у виробництві і споживанні, появу безробіття, виникнення економічної кризи і стагнації;

по-друге, побудувати модель утворення прибутку в реальному секторі економіки;

по-третє, виявити особливості виробництва інноваційної продукції і інноваційного процесу в сучасній економічній системі.

Робиться висновок, про те, що саме система, або глибина розподілу праці, в якій знаходиться те чи інше виробництво визначає його ефективність 
Наукова новизна проведеного дослідження полягає в запропонованому методологічному підході до аналізу причин економічної кризи і основних чинників економічного зростання. Визначається система технологічного i економічного відтворення, як об'єкт по відношенню до якого досліджується глибина розподілу праці. Єдиним базовим ресурсом системи відтворення $€$ праці, і відповідно, іiї продуктивність визначається системою розподілу в якій вона використовується. Усі інші матеріальні ресурси системи відтворення $\epsilon$ похідним і розкладаються на витрати живої і уречевленої праці.

\section{Література:}

1. Schmmpeter J. A. Histori Economic Analysis / J. A. Schmmpeter. - London: George Allen \& Unwin, 1954. - Pp. 968.

2. Абалкин Л. И. Избраные труды. В 4-х тт./Л. И. Абалкин. - М.: Экономика, 2000.

3. Гальчинський А. С. Глобальні трансформації: концептуальні альтернативи: Методологічні аспекти / А. С. Гальчинський / Інститут стратегічних оцінок. - К.: Либідь, 2006. - 310с.

4. Гєлбрейт Дж. Новое индустриальное общество / Дж. Гэлбрейт; пер. с англ. - М.:ООО «Издательство АСТ»: «Транзиткнига»; СПб.:Terra Fantastica, 2004. - 602 с.

5. Макконел К. Экономикс. Принципы, проблемы и политика / К. Макконел, С. Брю М.: Инфра, 2005. -940.

6. Маркс К. Капитал. Критика политической экономии / К. Маркс. Т. І, кн. І. Процесс производства капитала. - М.: Политиздат, 1978. - 891 с.

7. Мілай А. О. Особливості та наслідки проведення грошово-кредитної політики ФРС США в умовах світової економічної кризи / А. О. Мілай// Економічний вісник НТУУ»КПІ»: зб. наук. праць. - К.: ВПК «Політехніка» - 2014. - №11. - С. 91-96.

8. Мілай А. О. Методологічний підхід к дослідженню економічної природи фірми / А. О. Мілай // Економічний вісник НТУУ «КПІ»: зб. наук. праць. - К.: ВПК «Політехніка» - 2015. - №12. - С.8-13.

9. Пріоритети національного економічного розвитку в контексі глобальних викликів: [монографія]: у 2-х частинах - Ч-1 / за ред. В. М. Гейця, А. А. Мазаракі. - К.: Київський нац.торг.- екон. ун-т, 2008. -389 с.

10. Смит А. Исследование о природе и причинах богатства народов./ А.Смит. М.: Эксмо, -2007. - 960с. 